\title{
Cold storage of peaches cv. Aurora grown in the Zona da Mata Mineira, Minas Gerais State, Brazil ${ }^{1}$
}

\author{
Danielle Fabíola Pereira Silva², Mariana Rodrigues Ribeiro ${ }^{3}$, José Osmar da Costa e Silva \\ Rosana Gonçalves Pires Matias ${ }^{4}$, Claudio Horst Bruckner 5
}

\begin{abstract}
This study aimed to evaluate the postharvest behavior of peach cv. Aurora 1 harvested in the Zona da Mata region of Minas Gerais in two ripening stages and kept under different storage temperatures. Fruits on mid-ripe and fully ripe stages were stored at three temperatures: $5.6 \pm 1.57^{\circ} \mathrm{C}$ and $72.8 \pm 3.8 \% \mathrm{RH} ; 10.4 \pm 0.5^{\circ} \mathrm{C}$ and $95.8 \pm 5.5 \% \mathrm{RH} ; 21.04 \pm 1.63$ ${ }^{\circ} \mathrm{C}$ and $96.9 \pm 2.6 \% \mathrm{RH}$ up to 28 storage days (SD) . During storage, fruits stored at $21.04 \pm 1.63{ }^{\circ} \mathrm{C}$ were evaluated every two days until $8 \mathrm{SD}$, and every four days for fruits stored at other temperatures. The harvest day was assigned as day zero. The variables evaluated were $\mathrm{CO}_{2}$ production, color of the pericarp and pulp, fresh mass loss, flesh firmness, total soluble solids, titratable acidity, contents of ascorbic acid and carotenoids. The fresh mass loss increased during storage, peaking at $5.6^{\circ} \mathrm{C}$. The reduction in ascorbic acid content was higher in fully ripe fruits at all temperatures. Midripe fruits reached the end of the storage period with better quality. The temperature of $10.4{ }^{\circ} \mathrm{C}$ was the most efficient in keeping postharvest quality of peach cv. Aurora 1 harvested in the Zona da Mata region.
\end{abstract}

Key words: Prunus persica, ripening stage, fruit quality.

\section{RESUMO}

\section{Conservação refrigerada de pêssego cv. Aurora, cultivado na Zona da Mata Mineira}

Este trabalho teve como objetivo avaliar o comportamento pós-colheita de frutos de pessegueiro 'Aurora 1', colhidos na região da Zona da Mata Mineira, em dois estádios de maturação, mantidos sob diferentes temperaturas de armazenamento. Lotes de frutos nos estádios de maturação "de vez" e maduro foram armazenados em três temperaturas: $5,6 \pm 1,57^{\circ} \mathrm{Ce} 72,8 \pm 3,8 \% \mathrm{UR} ; 10,4 \pm 0,5^{\circ} \mathrm{C}$ e $95,8 \pm 5,5 \% \mathrm{UR} ; 21,04 \pm 1,63{ }^{\circ} \mathrm{Ce} 96,9 \pm 2,6 \%$ UR, por até 28 dias de armazenamento (DA). Durante o armazenamento, os frutos foram avaliados a cada dois dias, até o $8^{\circ} \mathrm{DA}$, para frutos armazenados em $21,04 \pm 1,63{ }^{\circ} \mathrm{C}$, e a cada quatro dias, para frutos armazenados nas demais temperaturas, sendo o dia zero o dia da colheita dos frutos. Foram avaliados a produção de $\mathrm{CO}_{2}$, a coloração do pericarpo e da polpa, a perda de massa de matéria fresca, a firmeza da polpa, o teor de sólidos solúveis, a acidez titulável, o teor de ácido ascórbico e o teor de carotenoides. A perda de matéria fresca aumentou durante o armazenamento, sendo mais acentuada na temperatura 5,6 ${ }^{\circ} \mathrm{C}$. A redução do teor de ácido ascórbico foi maior nos frutos maduros, para todas as temperaturas em estudo. Frutos no estádio de maturação "de vez" chegaram ao final do período de armazenamento com melhor qualidade, sendo a temperatura de $10,4{ }^{\circ} \mathrm{C}$ a mais eficiente na manutenção da qualidade pós-colheita de frutos de pêssego 'Aurora 1', colhidos na região da Zona da Mata Mineira.

Palavras-chave: Prunus persica, estádio de amadurecimento, qualidade do fruto.

Received: 20/09/2012 Accepted: 26/06/2013.

${ }^{1}$ Research developed with financial support from CAPES, CNPq and FAPEMIG.

${ }^{2}$ Agronomist Engineer, Doctor of Science. Departamento de Fitotecnia, Universidade Federal de Viçosa, Campus Viçosa, Avenida Peter Henry Rolfs, s/n, 36570-000, Viçosa, Minas Gerais, Brasil. danieele@ufv.br (corresponding author). Bolsista PNPD-CAPES.

${ }^{3}$ Undergraduate in Agronomy. Departamento de Agronomia, Universidade Federal de Viçosa, Campus Viçosa, Avenida Peter Henry Rolfs, s/n, 36570-000, Viçosa, Minas Gerais, Brasil. mariana.r.ribeiro@ufv.br

${ }^{4}$ Agronomist Engineer, Master of Science. Departamento de Fitotecnia, Universidade Federal de Viçosa, Campus Viçosa, Avenida Peter Henry Rolfs, s/n, 36570-000, Viçosa, Minas Gerais, Brasil. rosana.pires@ufv.br

${ }^{5}$ Agronomist Engineer, Doctor of Science. Departamento de Fitotecnia, Universidade Federal de Viçosa, Campus Viçosa, Avenida Peter Henry Rolfs, s/n, 36570-000, Viçosa, Minas Gerais, Brasil. bruckner@ufv.br 


\section{INTRODUCTION}

Progress in peach genetic improvement for subtropical regions has been highly significant. As a result, the production of peaches for industry and fresh consumption extended to new areas in subtropical regions as well as the marketing period (Wagner Jr. et al., 2011).

Cultivar Aurora 1 has a low requirement of cold temperature to break dormancy (under 100 hours) and fruits of high sensory quality. Fruit is oblong shaped and weight is around 90-110 g. The skin color is red ( $80 \%$ color over yellow background). The flesh is firm, pale yellow, adhered to the stone. Soluble solids are, on average, $14^{\circ}$ Brix, with low acidity (Cunha Júnior et al., 2007).

The ripening stage at harvest is crucial for postharvest life as well as for storage potential. Thus, when the fruits are harvested before physiological maturity they will not ripen, will become shriveled and ooze sap, or if ripening occurs, leads to a poor quality fruits. Overripe fruits deteriorate rapidly and cannot be stored and/or marketed in distant locations (Silva et al., 2012).

Chilling is among the methods used to extend the postharvest life of fruits (Silva et al., 2009). According to Souza et al. (2009), refrigerated storage slows the plant metabolism by decreasing the respiratory rate and the enzymatic activity. Peach has a climacteric respiratory pattern and after harvesting the fruit physiologically ripe, changes triggered by ethylene production and increased respiratory rate occur rapidly (Brackmann et al., 2009). Fruits of cv. Aurora 1 grown in the municipality of Taiúva - SP and stored for 35 days at $2{ }^{\circ} \mathrm{C}, 6^{\circ} \mathrm{C}$ and $12{ }^{\circ} \mathrm{C}$, showed no sensitivity to cold (Cunha Júnior et al., 2010).

Little is known about the effects of cold storage at different stages of maturation of peaches grown in subtropical regions. The experimental conditions used by many authors are quite varied with regard to the place of cultivation, cultivars and storage temperatures. In southern Brazil, the technology of cold storage for temperate fruits is widespread. For Minas Gerais State to gain ground in this market with efficiency, the development and improvement of farming and postharvest techniques are needed to increase shelf life and, at the same time, ensure fruit quality to the final consumer.

Thus, establishing the appropriate harvest point and optimum temperature for stone fruit storage can minimize quality loss during storage. Therefore, this study aims to evaluate the quality of peaches cv. Aurora 1 under different storage temperatures, when harvested at different ripening stages.

\section{MATERIALS AND METHODS}

Fruits of peach (cv. Aurora 1) were collected from trees growing in the municipality of Barbacena - MG (located at $21^{\circ} 13^{\prime} 33^{\prime \prime} \mathrm{S}$ and $43^{\circ} 46^{\prime} 25^{\prime \prime} \mathrm{O}, 1.164 \mathrm{~m}$ altitude). The climate is highland tropical (CWB), with cold winters and mild summers. The average annual temperature is $17^{\circ} \mathrm{C}$, with a maximum average of $24.17 \pm 1.75^{\circ} \mathrm{C}$ and minimum average of $13.58 \pm 2.27^{\circ} \mathrm{C}$.

Mid-ripe and fully ripe fruits were harvested on October 25, 2011, in the early hours of the day. Visually, mid-ripe fruits were considered those with green color background and no, or little, red color covering the skin. When picked, they had coordinate $b$ for skin color of 12.43; hue angle of 92.10 and soluble solids were $8.73^{\circ}$ Brix. Fully ripe peaches were considered those changing background skin color from green to creamy-white and abundant red color covering the skin (Seibert et al., 2008). When picked, they had coordinate $b$ for skin color of 19.49; hue angle of 74.140 and soluble solids were $9.56{ }^{\circ}$ Brix.

After harvest, fruits were transported in cardboard boxes, in a refrigerated car, to the laboratory of Fruit Analysis at the Universidade Federal de Viçosa - MG. Fruits were sorted and sized by suture $(44.8 \pm 3.6)$, equatorial $(43.0 \pm 3.9)$ and polar $(51.5 \pm 3.5)$ diameters, ripening stage (mid-ripe and fully ripe), lack of decay and mechanical damage. They were washed in $0.2 \%$ detergent solution,

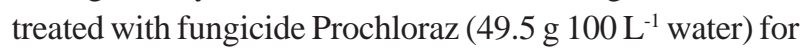
$5 \mathrm{~min}$ and allowed to air dry.

Then the peaches were separated by the instrumental method of skin color in lots containing mid-ripe (hue angle $87.16 \pm 3.06^{\circ}$ ) and fully ripe (hue angle $78.41 \pm 8.58^{\circ}$ ) fruits. According to Cunha Júnior et al. (2007), peaches are considered mid-ripe when reaching values between 98 and $110^{\circ}$ and fully ripe when reaching values between 90 and $110^{\circ}$.

Peaches were packed in polystyrene trays ( $220 \mathrm{~mm} \mathrm{x}$ $140 \mathrm{~mm} \times 40 \mathrm{~mm}$ ) and stored at three temperatures: $5.6 \pm$ $1.57^{\circ} \mathrm{C}$ and $72.8 \pm 3.8 \% \mathrm{RH} ; 10.4 \pm 0.5^{\circ} \mathrm{C}$ and $95.8 \pm 5.5 \%$ $\mathrm{RH}$; and $21.04 \pm 1.63{ }^{\circ} \mathrm{C}$ and $96.9 \pm 2.6 \% \mathrm{RH}$ for 28 days. During storage, fruits stored at $21.04 \pm 1.63{ }^{\circ} \mathrm{C}$ were evaluated every two days and fruits stored at the other temperatures were evaluated every four days. The harvest day was assigned as day zero.

The experiment was conducted in a split plot arrangement, with the temperatures (three levels) in the main plots, the ripening stages in the subplots (two levels) and the evaluation days (eight levels) in the subsubplots, in a the completely randomized design with three replicates of five fruits per experimental unit.

Fruits were analyzed for $\mathrm{CO}_{2}$ production by gas chromatography, using a Gow Mac Series 550P gas chromatograph equipped with a thermal conductivity 
detector and aluminium column filled with Porapak Q. The working conditions were: helium flow rate of $40 \mathrm{~mL}$ per minute, as the carrier gas, electric current of $150 \mathrm{~mA}$, column, detector and injector temperatures were 50, 70 and $80{ }^{\circ} \mathrm{C}$, respectively, and room temperature between 20 and $23{ }^{\circ} \mathrm{C}$. The results were expressed in $\%$ or in $\mathrm{mg}$ of $\mathrm{CO}_{2} \mathrm{~kg}^{-1} \mathrm{~h}$; fresh matter loss (gravimetric method), color of skin and pulp (digital colorimeter); pulp consistency (digital penetrometer probe of $12 \mathrm{~mm}$ ), soluble solids expressed in ${ }^{\circ}$ Brix (digital refractometer), titratable acidity (TA) (titration with $\mathrm{NaOH}$ and the results expressed as \% malic acid) according to the methodology described in AOAC ( 1997), vitamin C (titration reagent Tillman 2,6 dichlorophenolindophenol) according to the methodology described in AOAC (1997) and the results expressed in $\mathrm{mg} 100 \mathrm{~g}^{-1}$ of pulp, carotenoids (approximately $2.0 \mathrm{~g}$ ground in a mortar with washed sand, acetone $80 \%$ and a pinch of $\mathrm{CaCO}_{3}$. The ketone extract was filtered through filter paper and the volume was completed to $25 \mathrm{~mL}$. The absorbance was determined at 470, 646.8 and $663.2 \mathrm{~nm}$ and the levels of carotenoids calculated using the equations of Lichtenthaler (1987), in mg $100 \mathrm{~g}^{-1}$ of pulp.

Unfolding was used for data analysis, regardless of whether there was significant interaction or not, to demonstrate the behavior throughout the experimental period. Factor means were subjected to regression analysis. The models were chosen based on the significance of the regression coefficients, using the " $\mathrm{t}$ " test, the coefficient of determination $\left(\mathrm{R}^{2}\right)$ and the potential to explain the biological phenomenon. The descriptive statistical analysis was used for $\mathrm{CO}_{2}$ production.

\section{RESULTS AND DISCUSSION}

The respiratory peak of mid-ripe fruits stored at 5.6 ${ }^{\circ} \mathrm{C}$ occurred after 24 days (SD), with $18.7 \mathrm{mg}$ of $\mathrm{CO}_{2} \mathrm{~kg}^{-1} \mathrm{~h}^{-}$ ${ }^{1}$; for fruits stored at $10.4^{\circ} \mathrm{C}$, the peak occurred on day $20 \mathrm{SD}$ (Figures 1A and 1B). Fruits stored at $21.04{ }^{\circ} \mathrm{C}$ reached the climacteric peak on day $6 \mathrm{SD}$, with mid-ripe and fully ripe fruits with 15.1 and $14.5 \mathrm{mg}$ of $\mathrm{CO}_{2} \mathrm{~kg}^{-1} \mathrm{~h}^{-1}$, respectively (Figure 1C). Peaches cv. Douradão harvested at the commercial ripening stage and stored at $0{ }^{\circ} \mathrm{C}$ reached the peak on day $5 \mathrm{SD}$ with $25 \mathrm{mg}$ of $\mathrm{CO}_{2}$ $\mathrm{kg}^{-1} \mathrm{~h}^{-1}$ (Souza et al., 2009).

The loss of fresh matter had a linear decrease with days of storage (Figure 2). On day $8 \mathrm{SD}$, the mass loss was 15.2, 6.0 and $16.0 \%$ for mid-ripe fruits stored at 5.6, 10.4 and $21.04{ }^{\circ} \mathrm{C}$, respectively (Figures 2A, 2B and 2C). Fruits stored at $10.4{ }^{\circ} \mathrm{C}$ had, at the end of storage (28 days), accumulated mass loss of 21.1 and $19.5 \%$ for midripe and fully ripe stages, respectively (Figure 2B). Despite displaying more than $5 \%$ loss, the fruits showed no symptoms of shriveling, which would prevent its commercialization. Seibert et al. (2008) observed that peaches $\mathrm{cv}$. Chimarrita after 10 and 30 days of refrigerated storage, when brought to $20^{\circ} \mathrm{C}$, showed slight wilting in the shoulder region. This symptom was a little more intense in peaches harvested at ripe stage. The mass losses were greater than $5 \%$ and led to shriveling, especially in peaches harvested at mid-ripe stage and after 20 days of storage. Shriveling was observed in ripe peaches cv. Chiripá after 20 days at $0{ }^{\circ} \mathrm{C}$. Mitchell (1992) reported 5\%
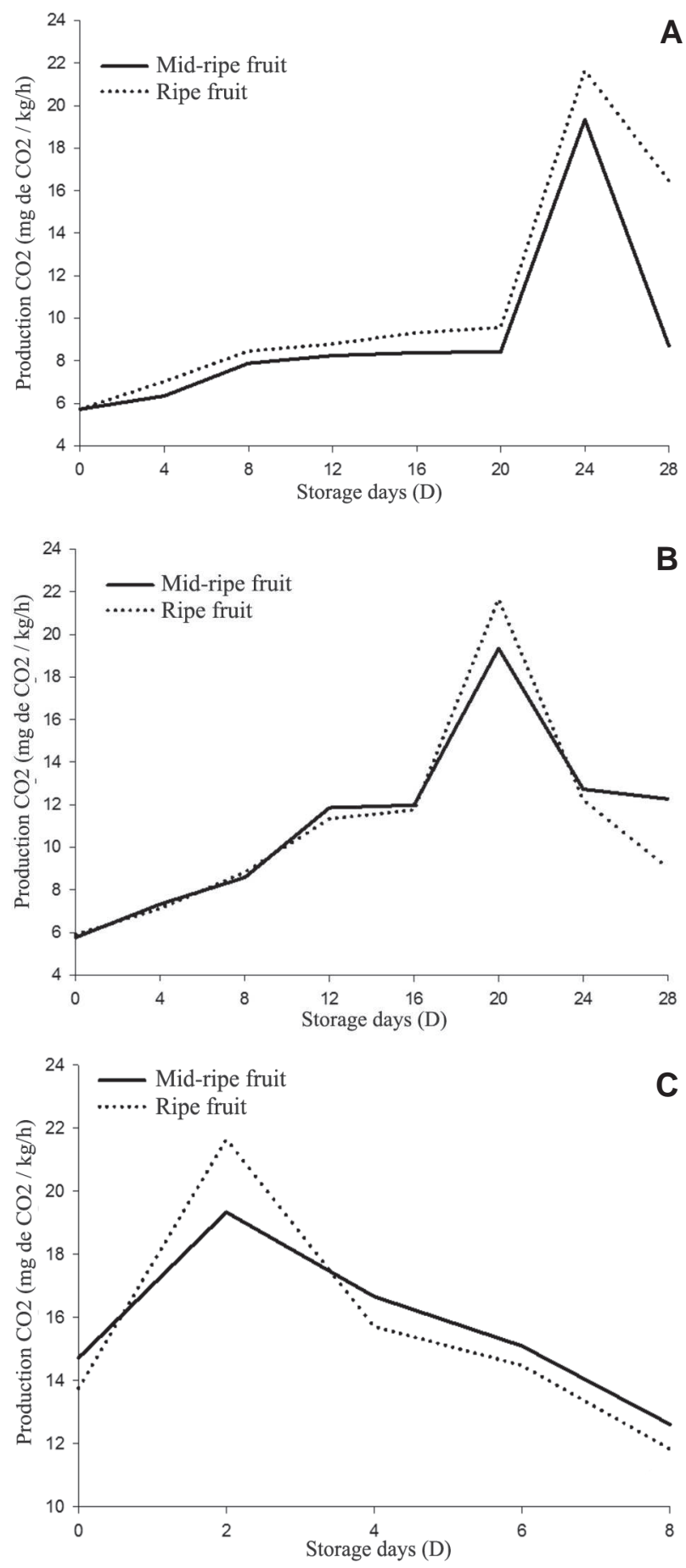

Figure 1. $\mathrm{CO}_{2}$ production in peaches cv. Aurora 1 harvested at mid-ripe and fully ripe stages during storage at different temperatures (A: $5.6{ }^{\circ} \mathrm{C}$; B: $10.4{ }^{\circ} \mathrm{C}$; and C: $20.04{ }^{\circ} \mathrm{C}$ ).

Rev. Ceres, Viçosa, v. 60, n.6, p. 833-841, nov/dez, 2013 
mass loss as a limit, before the peaches loose quality. For Crisosto et al. (2004), mass losses of 5\% are normal for peaches and shriveling symptoms are noticed when they exceed $10 \%$. For the cultivars Chimarrita and Chiripá, a loss limit of $5 \%$ and higher percentages can lead to symptoms of shriveling (Seibert et al., 2008).

Peaches harvest at the different ripening stage presented similar trend regarding skin and pulp color
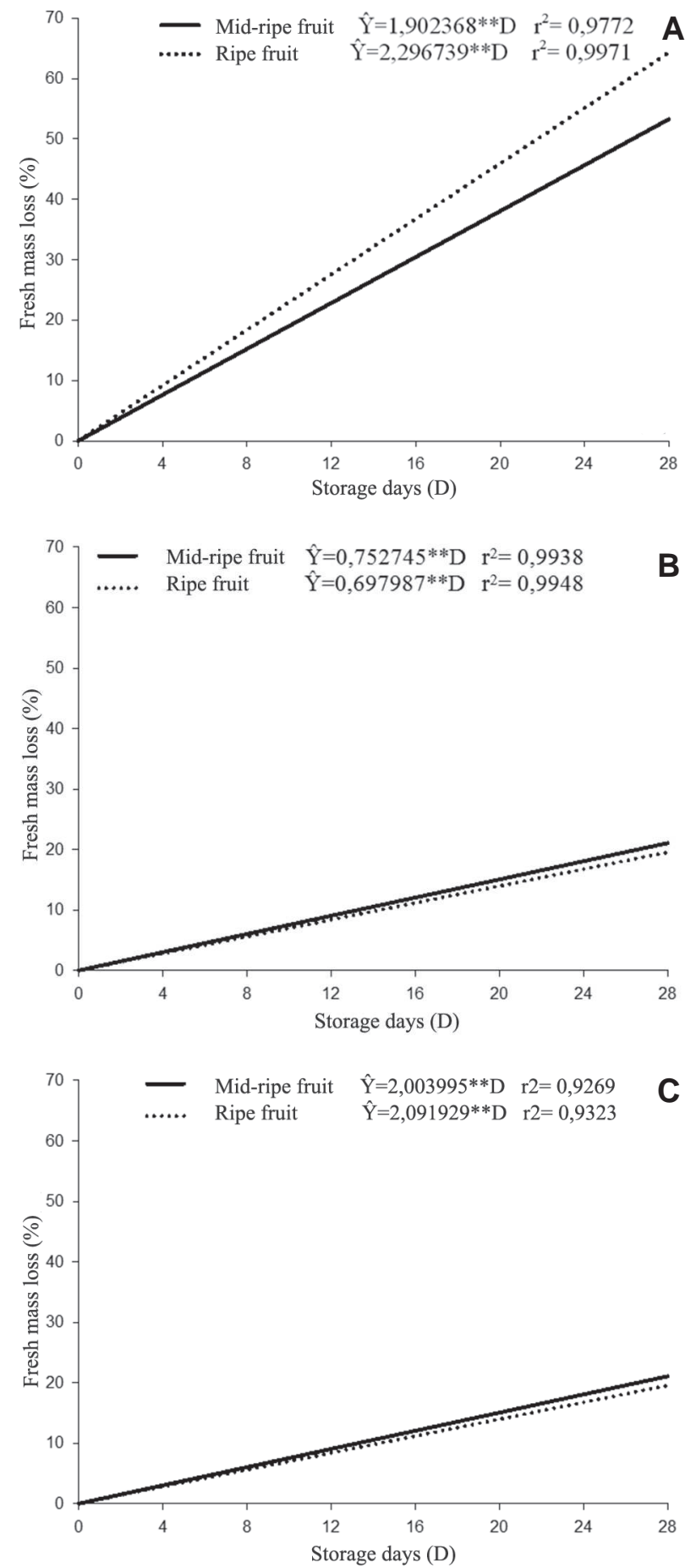

Figure 2. Fresh mass loss of peaches cv. Aurora 1 harvested at mid-ripe and fully ripe stages during storage at different temperatures (A: $5.6{ }^{\circ} \mathrm{C}$; B: $10.4{ }^{\circ} \mathrm{C}$; and C: $20.04{ }^{\circ} \mathrm{C}$ ).
(Figures 3, 4, 5 and 6) and the temperature of $5.6{ }^{\circ} \mathrm{C}$ resulted in the smaller changes. The skin color of midripe fruit stored at $10.4{ }^{\circ} \mathrm{C}$ had little change from the first day of evaluation (harvest day), which may allow extend the marketing period up to 28 days, without compromising the visual quality of the fruit. Mid-ripe fruit stored at $5.6{ }^{\circ} \mathrm{C}$, had minor changes in skin color, however, there was impairment of fruit visual quality
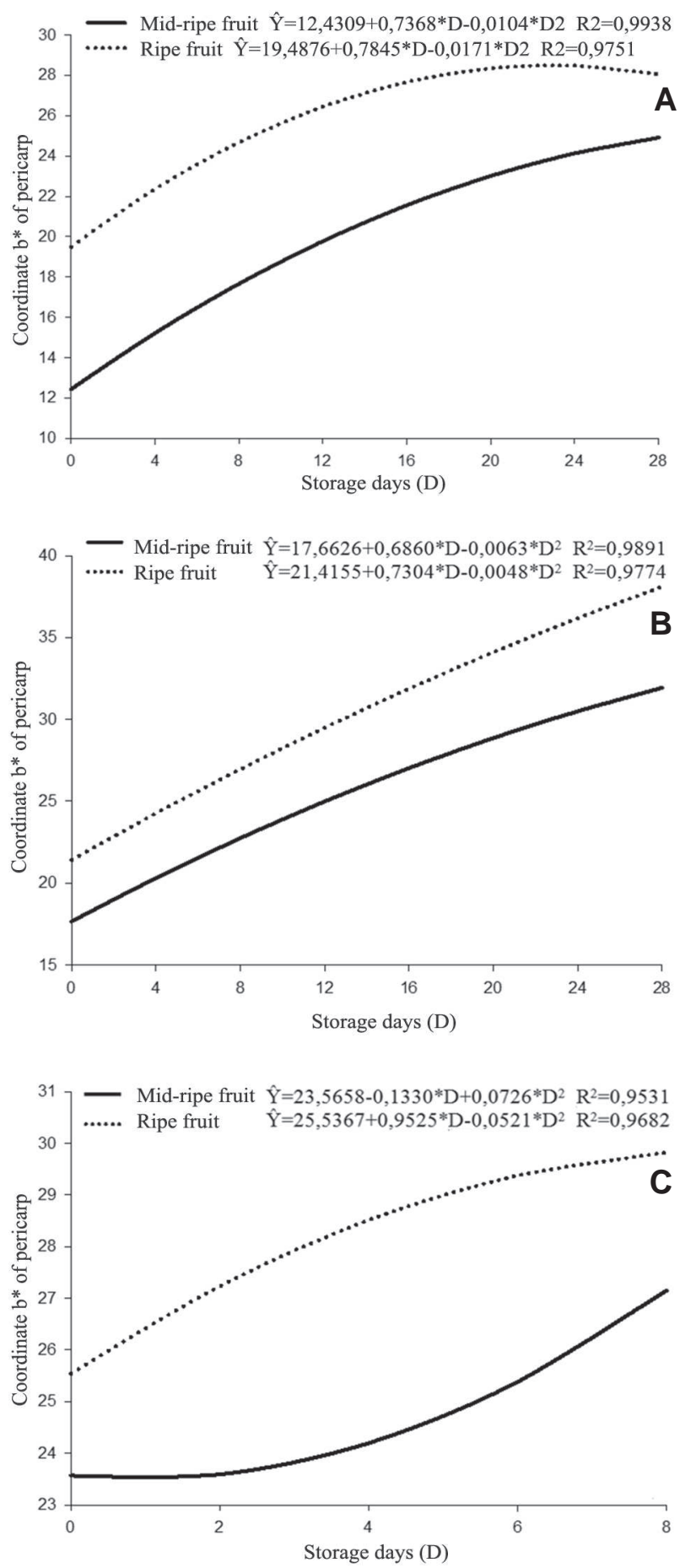

Figure 3. Coordinate $b^{*}$ of pericarp of peaches cv. Aurora 1 harvested at mid-ripe and fully ripe stages during storage at different temperatures (A: $5.6{ }^{\circ} \mathrm{C}$; B: $10.4{ }^{\circ} \mathrm{C}$; and C: $20.04{ }^{\circ} \mathrm{C}$ ). 
because of the high loss of fresh mass at the end of storage. A trend for color maintenance at low temperatures was also observed by Bron et al. (2002), who reported decreased levels of hue angle in fruits of cultivars Aurora 1 and Golden 2 with storage, as well as that fruit stored at lower temperatures resulted in less reduction of this variable compared with those stored at room temperature.
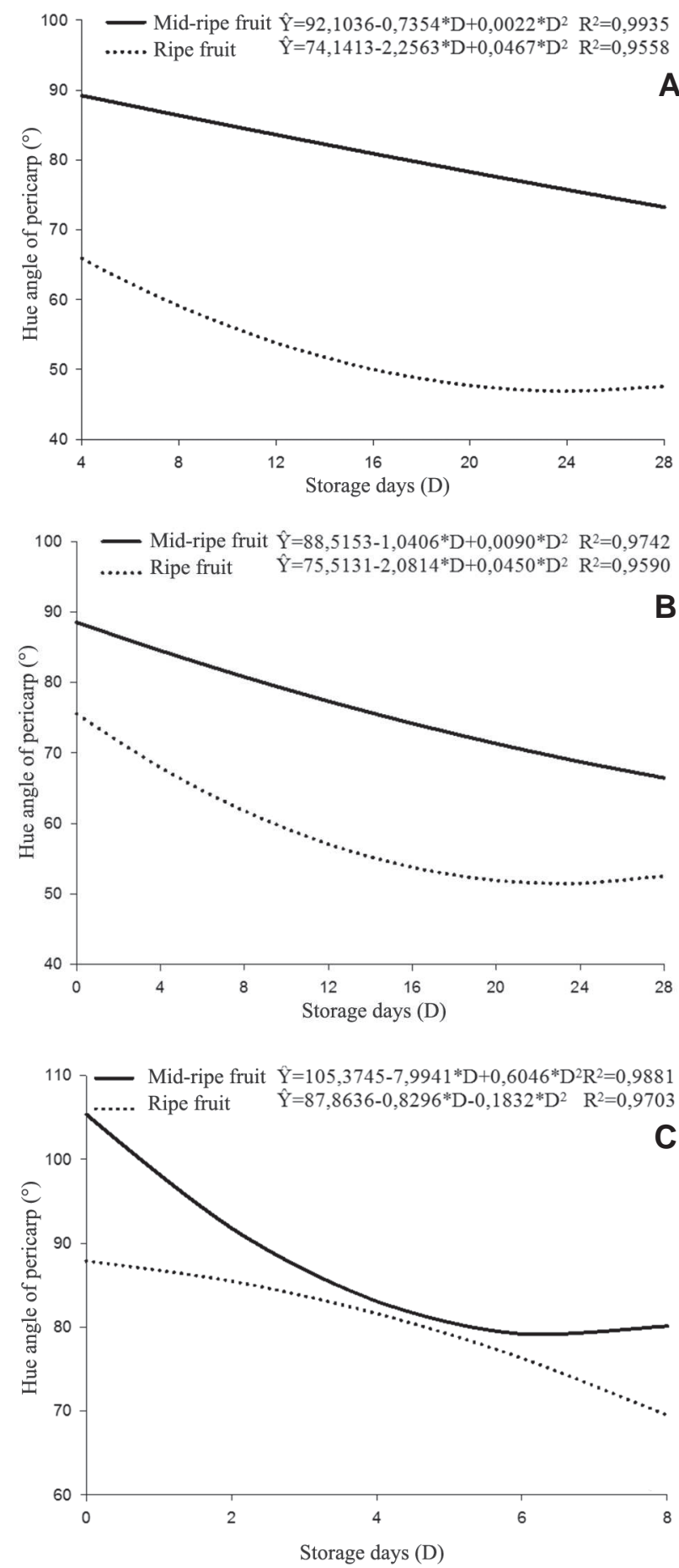

Figure 4. Hue angle of pericarp of peaches cv. Aurora 1 harvested at mid-ripe and fully ripe stages during storage at different temperatures (A: $5.6{ }^{\circ} \mathrm{C}$; B: $10.4{ }^{\circ} \mathrm{C}$; and C: $20.04{ }^{\circ} \mathrm{C}$ ).
Fruits of all treatments showed a decrease of pulp consistency during storage, regardless of the temperature and the ripening stage (Figure 7). On day $8 \mathrm{SD}$, fruits stored at $21.04{ }^{\circ} \mathrm{C}$ showed consistency of 21.58 and 10.33 $\mathrm{N}$ for mid-ripe and fully ripe fruit stages, respectively, while for mid-ripe fruit stored 5.6 and $10.4{ }^{\circ} \mathrm{C}$, consistency over the same period was 47.49 and $44.58 \mathrm{~N}$, respectively, which demonstrates the potential of lower temperatures to con-
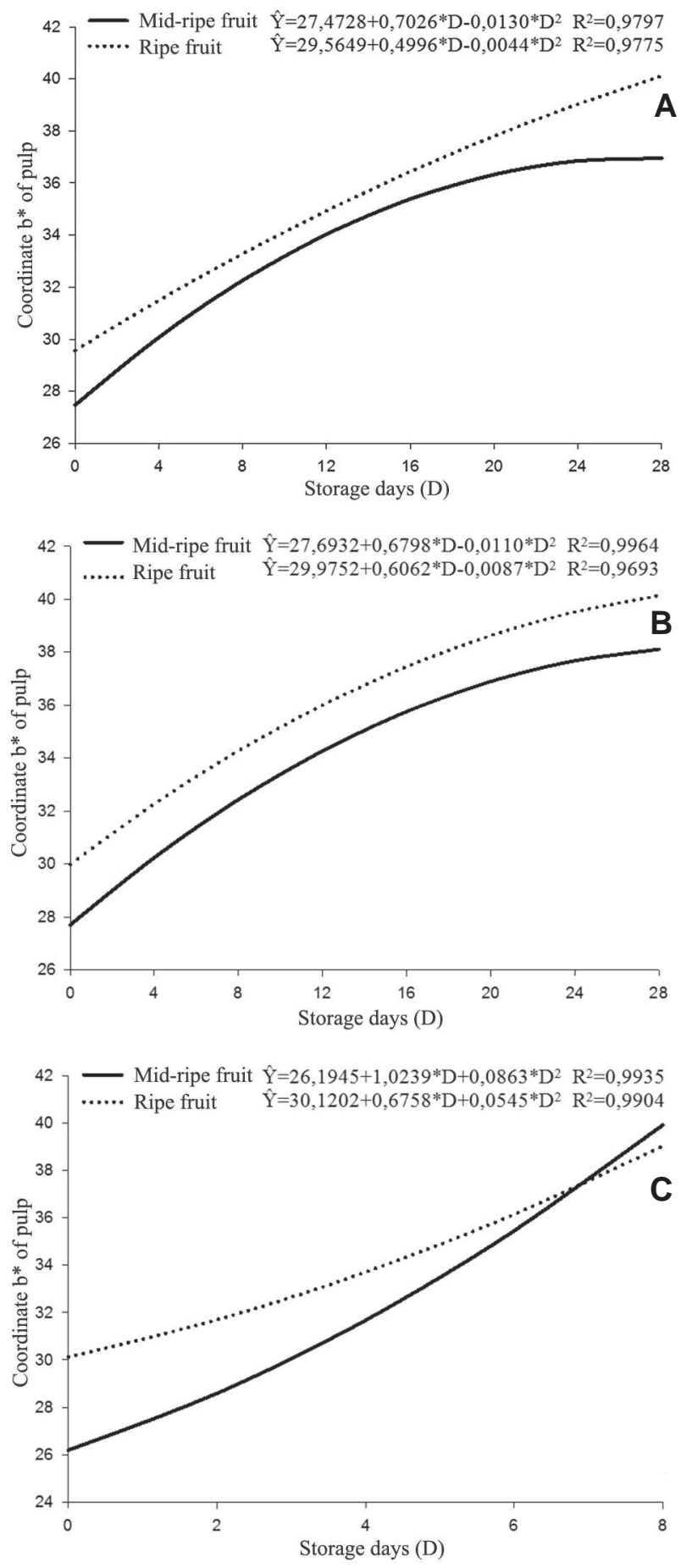

Figure 5. Coordinate $b^{*}$ of pulp of peaches cv. Aurora 1 harvested at mid-ripe and fully ripe stages during storage at different temperatures (A: $5.6{ }^{\circ} \mathrm{C}$; B: $10.4{ }^{\circ} \mathrm{C}$; and C: $20.04{ }^{\circ} \mathrm{C}$ ).

Rev. Ceres, Viçosa, v. 60, n.6, p. 833-841, nov/dez, 2013 
serve the fruit for longer periods. Cunha Júnior et al. (2010), studying the cold storage of peaches cv. Aurora 1 produced in Taiúva - SP, observed that ripe fruit stored at $12{ }^{\circ} \mathrm{C}$ had a sudden reduction in firmness, reaching 14 days SD with 7.9 N. Mid-ripe peaches had initial values of $46.5 \mathrm{~N}, 21.1 \mathrm{~N}$ in the same period. In this work, we observed that the ripe fruit stored at $10.4{ }^{\circ} \mathrm{C}$ had consistency of $25.37 \mathrm{~N}$ on day $16 \mathrm{SD}$, while mid-ripe fruits
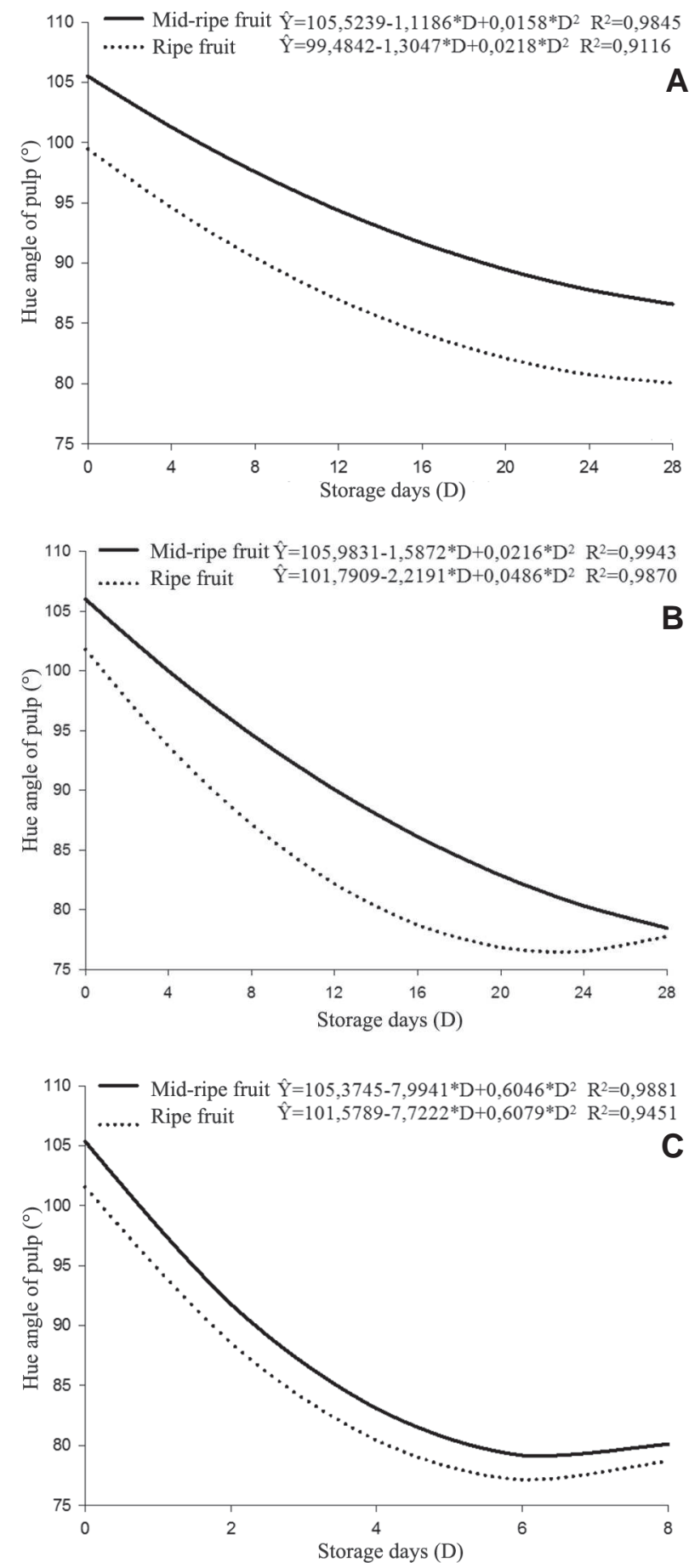

Figure 6. Hue angle of pulp of peaches cv. Aurora 1 harvested at mid-ripe and fully ripe stages during storage at different temperatures (A: $5.6{ }^{\circ} \mathrm{C}$; B: $10.4{ }^{\circ} \mathrm{C}$; and C: $20.04{ }^{\circ} \mathrm{C}$ ). had consistency of $34.56 \mathrm{~N}$. Peaches with low firmness have a lower transport resistance and, consequently, shorter shelf life (Toebe et al., 2011).

Both mid-ripe and fully ripe fruit reached at the end of storage SS contents of 16 and $21.1^{\circ}$ Brix, respectively (Figure 8). However, these levels of SS are due to the high fresh matter loss on day $28 \mathrm{SD}$, reaching 53.3 and $64.3 \%$ cumulative loss for mid-ripe and fully ripe fruit, respectively.
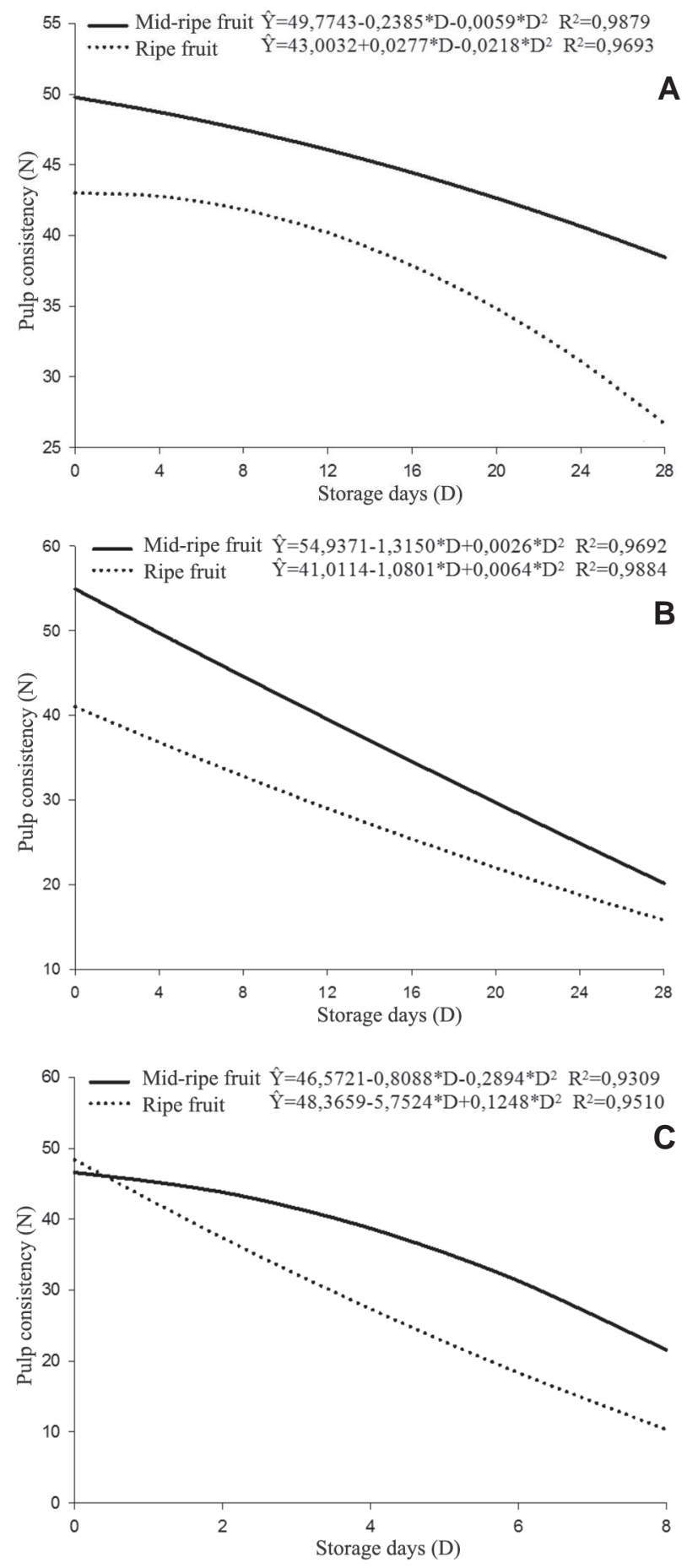

Figure 7. Pulp consistency of peaches cv. Aurora 1 harvested at mid-ripe and fully ripe stages during storage at different temperatures (A: $5.6{ }^{\circ} \mathrm{C}$; B: $10.4{ }^{\circ} \mathrm{C}$; and $\mathrm{C}: 20.04{ }^{\circ} \mathrm{C}$ ). 
At the other temperatures in this study, these levels were between 8.5 and $10.3^{\circ}$ Brix. Similar results were found by Cunha Júnior et al. (2010), who working with cv. Aurora 1, observed that mid-ripe fruits had lower SS (10.9 ${ }^{\circ}$ Brix $)$ than fully ripe fruits $\left(11.6^{\circ} \mathrm{Brix}\right)$.

The titratable acidity (TA) had a quadratic behavior along the days in all treatments (Figure 9). Ripe fruits showed lower TA when compared with mid-ripe fruits. According to Silva
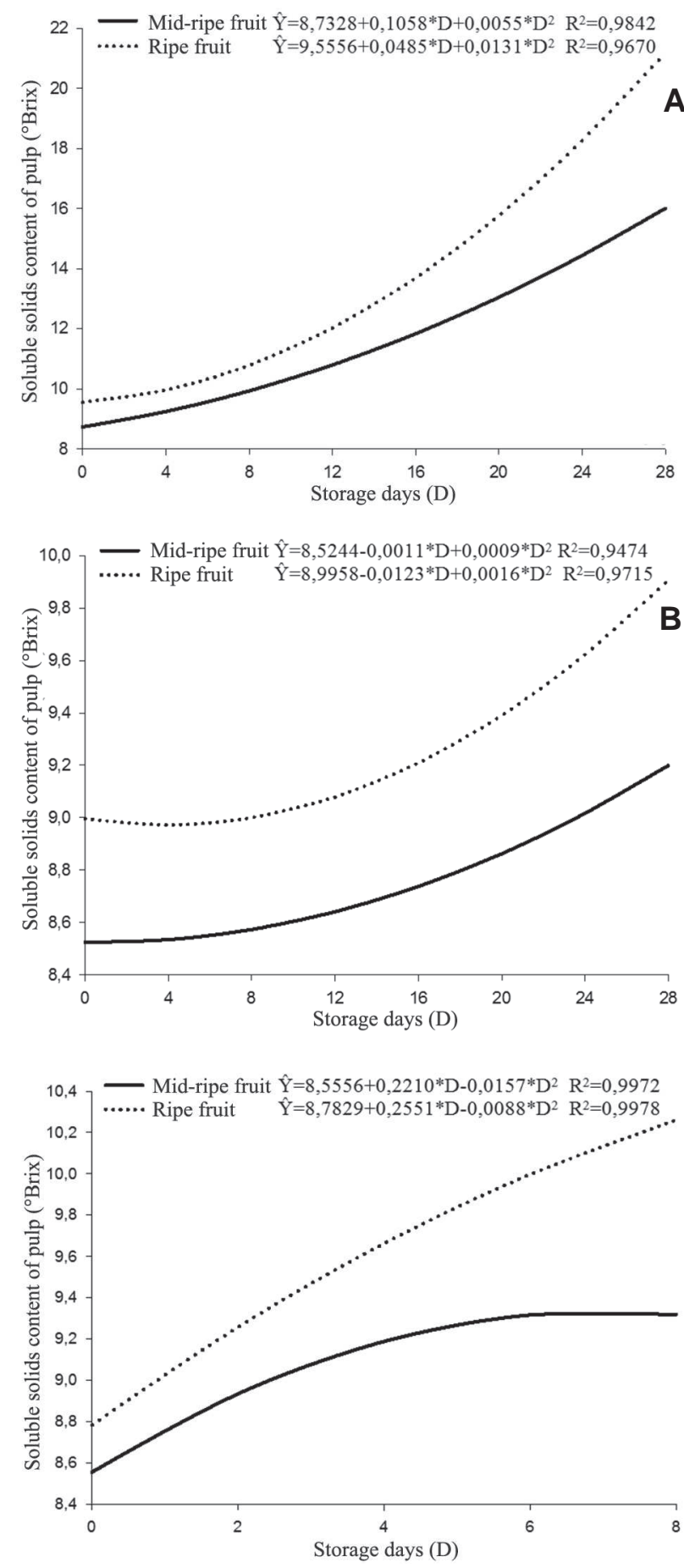

Figure 8. Soluble solids content of pulp of peaches cv. Aurora 1 harvested at mid-ripe and fully ripe stages during storage at different temperatures (A: $5.6{ }^{\circ} \mathrm{C}$; B: $10.4{ }^{\circ} \mathrm{C}$; and C: $20.04{ }^{\circ} \mathrm{C}$ ). et al. (2010), the levels of organic acids, with few exceptions, tend to decrease with fruit ripening, due to the respiratory process or their conversion into sugars.

The vitamin $\mathrm{C}$ content decreased according the quadratic model throughout the storage (Figure 10). Ripe fruits showed lower ascorbic acid content when compared with mid-ripe fruits, and that the greatest losses occurred at $20.04{ }^{\circ} \mathrm{C}$, when the ascorbic acid content of mid-ripe
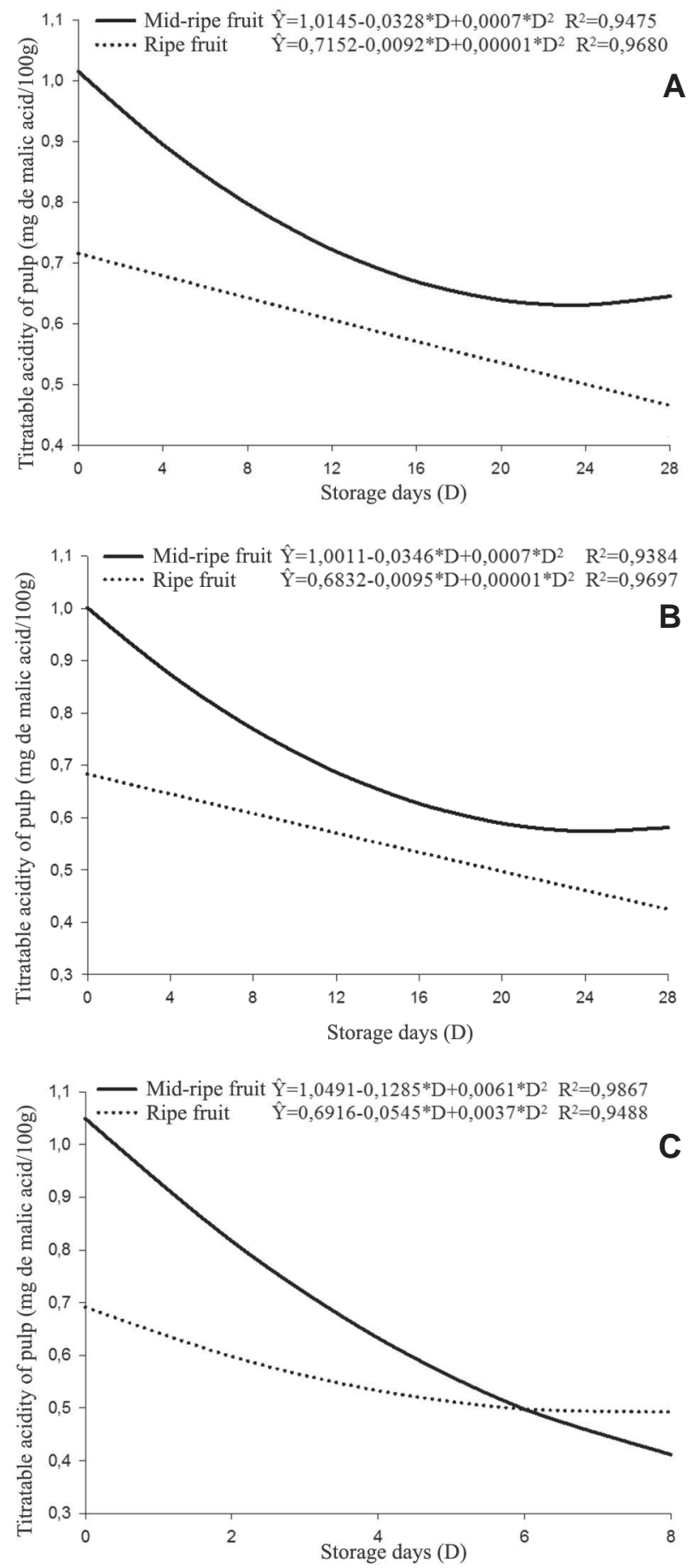

Figure 9. Titratable acidity of pulp of peaches cv. Aurora 1 harvested at mid-ripe and fully ripe stages during storage at different temperatures (A: $5.6{ }^{\circ} \mathrm{C}$; B: $10.4{ }^{\circ} \mathrm{C}$; and C: $20.04{ }^{\circ} \mathrm{C}$ ).

Rev. Ceres, Viçosa, v. 60, n.6, p. 833-841, nov/dez, 2013 
fruits decreased from $16.50 \mathrm{mg}$, on the harvest day, to $10.23 \mathrm{mg} 100 \mathrm{~g}^{-1}$ on day $8 \mathrm{SD}$. In most fruits, the vitamin C content tends to decrease during the ripening process. Silva et al. (2012) attributes this decrease to the action of ascorbic acid oxidase (ascorbate oxidase). The activity of this enzyme is larger in ripe fruits than in unripe fruits, which may explain the losses during the fully ripe stage. Segantini et al. (2012), characterizing the pulp of different
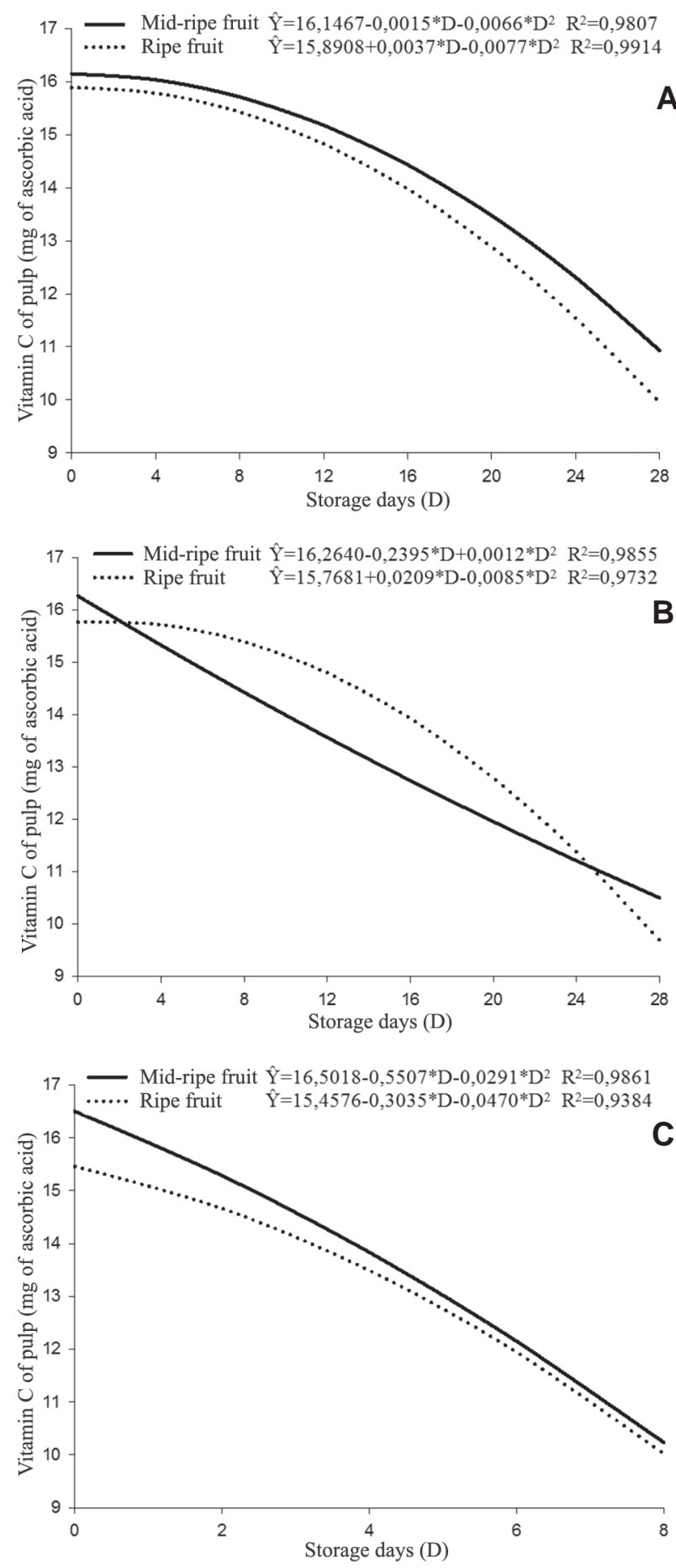

Figure 10. Vitamin C of pulp of peaches cv. Aurora 1 harvested at mid-ripe and fully ripe stages during storage at different temperatures (A: $5.6{ }^{\circ} \mathrm{C}$; B: $10.4{ }^{\circ} \mathrm{C}$; and C: $20.04{ }^{\circ} \mathrm{C}$ ). peach cultivars, found ascorbic acid content of $16.02 \mathrm{mg}$ $100 \mathrm{~g}^{-1}$ for fully ripe fruit of cv. Aurora 1.

The content of carotenoids was higher in ripe fruits and there was increase in their amounts in all treatments (Figure 11). The content of carotenoids increases during fruit ripening and color intensification is due to the loss of chlorophyll ( Melendez-Martinez, 2004). The content of total carotenoids increased during the ripening of many
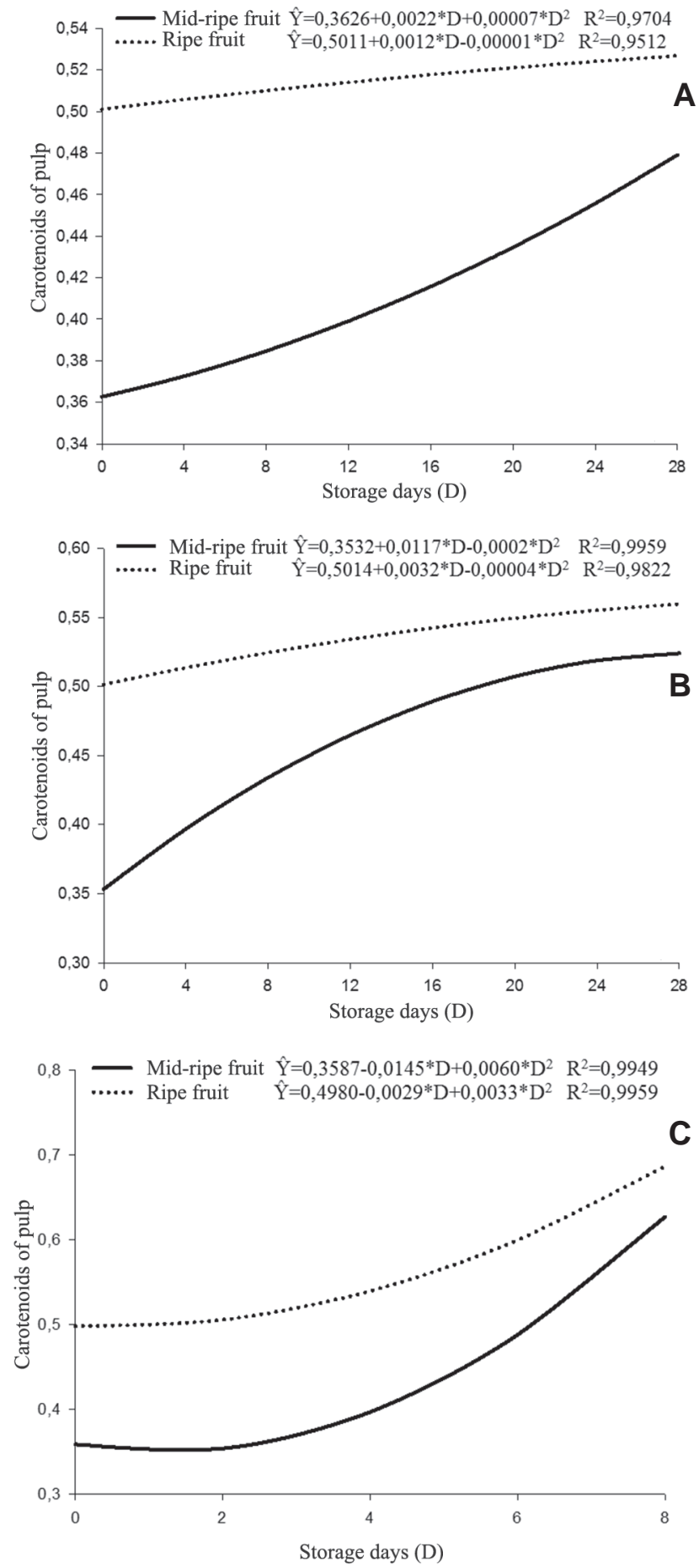

Figure 11. Carotenoids of pulp of peaches cv. Aurora 1 harvested at mid-ripe and fully ripe stages during storage at different temperatures (A: $5.6{ }^{\circ} \mathrm{C}$; B: $10.4{ }^{\circ} \mathrm{C}$; and $\mathrm{C}: 20.04{ }^{\circ} \mathrm{C}$ ). 
fruits, when carotenogenesis is enhanced (Lima et al., 2002), as in mango (Silva et al., 2012).

\section{CONCLUSION}

For the characteristics evaluated in this study, the best efficiency in maintaining postharvest quality of peaches cv. Aurora 1, cultivated in the Zona da Mata region, Minas Gerais, was obtained with fruits harvested at the midripe stage and kept at the temperature of $10.4{ }^{\circ} \mathrm{C}$.

\section{ACKONOWLEDGEMENTS}

The authors thank CAPES, CNPq and FAPEMIG for the financial support.

\section{REFERENCES}

AOAC (1997) Official methods of analysis of the Association of Official Analytical Chemists International. $16^{\text {th }}$ ed. Washington, AOAC. 1119 p.

Brackmann A, Pavanello EP, Both V, Weber A \& Pinto JAV (2009) Atmosfera refrigerada e controlada para pêssegos 'Eragil'. Ciência Rural, 39:2010-2015.

Bron IU, Jacomino AP \& Gloria BA (2002) Alterações anatômicas e físico-químicas associadas ao armazenamento refrigerado de pêssego 'Aurora-1' e 'Dourado-2'. Pesquisa Agropecuária Brasileira, 37:1349-1358.

Crisosto CH, Garner D, Andris HL \& Day KR (2004) Controlled delayed cooling extends peach market life. Hort Technology, 14:99-104.

Cunha Junior LC, Durigan MFB \& Mattiuz BH (2010) Conservação de pêssegos 'Aurora-1' armazenados sob refrigeração. Revista Brasileira de Fruticultura, 32:386-396.

Cunha Junior LC, Durigan MFB, Mat-tiuz BH, Martins RM \& Durigan JF (2007) Caracterização da curva de maturação de pêssegos 'Aurora- 1', na região de Jaboticabal-SP. Revista Brasileira de Fruticultura, 29:661-665.

Lichtenthaler HK (1987) Chlorophylls and carotenoids: Pigments of photosynthetic biomembranes. Methods in Enzymology, 148:349-382.

Lima VLAG, Melo EA \& Lima DE (2002) Fenólicos e carotenoides totais em pitanga. Scientia Agricola, 59:447-450.

Meléndez-Martínez AJ (2004) Importancia nutricional de pigmentos carotenoides. Archivos Latinoamericanos de Nutrición, 54:149-155.

Mitchell FG (1992) Postharvest handling systems: Temperate zone tree fruits (Pome fruits and stone fruits) In: Kader AA (Ed.) Postharvest technology of horticultural crops. $2^{\text {nd }}$ ed. Oakland, University of California. p.215-221.

Segantini DM, Leonel S, Lima GPP, Costa SM \& Ramos A (2012) Caracterização da polpa de pêssegos produzidos em São Manuel-SP. Ciência Rural, 42:51-57.

Seibert E, Casali ME, Leão ML de, Pezzi E, Corrent AR \& Bender RJ (2008) Danos de frio e alterações qualitativas durante armazenagem refrigerada de pêssegos colhidos em dois estádios de maturação. Bragantia, 67:1021-1029.

Silva DFP da, Salomão LCC, Siqueira DL de, Cecon PR, Rocha A \& Struiving TB (2012) Amadurecimento de manga 'Ubá' com etileno e carbureto de cálcio na pós-colheita. Ciência Rural, 42:213-220.
Silva DFP da, Salomão LCC, Cecon PR \& Siqueira DL de (2010) Absorvedor de etileno na conservação de mamão Golden, armazenado à temperatura ambiente. Revista Ceres, 57:706-715.

Silva DFP da, Salomão LCC, Siqueira DL de, Cecon PR \& Rocha A (2009) Potassium permanganate effects in postharvest conservation of the papaya cultivar Sunrise Golden. Pesquisa Agropecuária Brasileira, 44:669-675.

Souza AV de, Kohatsu DS, Lima GPP \& Vieites RL (2009) Conservação pós-colheita de pêssego com o uso da refrigeração e da irradiação. Revista Brasileira de Fruticultura, 31:1184-1189.

Toebe M, Both V, Filho AC, Brackmann A \& Storck L (2011) Dimensionamento amostral para avaliar firmeza de polpa e cor da epiderme em pêssego e maçã. Revista Ciência Agronômica, 42:1026-1035.

Wagner Júnior A, Santos CEM \& Bruckner CH (2011) Seleção de progênies e genitores de pessegueiro com base nas características dos frutos. Revista Brasileira de Fruticultura, 33:170-179. 